\title{
Seroprevalence of Brucella suis in eastern Latvian wild boars (Sus scrofa)
}

\author{
Lelde Grantina-levina* (0, Jelena Avsejenko, Svetlana Cvetkova, Dita Krastina, Madara Streikisa, \\ Zanete Steingolde, Indra Vevere and leva Rodze
}

\begin{abstract}
Brucellosis due to Brucella suis biovar 2 is one of the most important endemic diseases in wild boar (Sus scrofa) populations in Europe. The aim of the present study was to determine the seroprevalence of brucellosis in wild boars in the eastern part of Latvia. Wild boars killed by hunters in the period from January to April $2015(n=877)$ and from March to April in $2016(n=167)$ were examined for antibodies against B. suis by the Rose Bengal test (RBT), a complement fixation test (CFT), and by enzyme-linked immunosorbent assays. In 2015, 199 samples (22.7\%) were positive by RBT and/or CFT while 36 samples (21.6\%) were seropositive in 2016. Of the Brucella seropositive samples from 2015 and 2016 ( $n=235), 162$ (68.9\%) were also seropositive to Yersinia enterocolitica. Considering cross-reactivity of serological tests, the seroprevalence of B. suis biovar 2 exposure in wild boars in the eastern part of Latvia was calculated to 14.0\% in 2015 and 9.6\% in 2016. From selected seropositive samples (42 in 2015 and 36 in 2016) total DNA was extracted and analyzed with an IS711-based nested polymerase chain reaction (PCR) assay. Species and biovar identification was conducted for bacteria isolated in monoculture from PCR positive samples by species specific primers and Bruce-ladder multiplex PCR. Brucella suis biovar 2 was isolated from 12/20 samples in 2015 and 9/9 samples in 2016. The average seroprevalence was relatively low compared to that found in certain other European countries. Males and females had an equal level of seropositivity, but a positive age-trend was observed for both males and females.
\end{abstract}

Keywords: Brucella suis, Brucellosis, Latvia, Sus scrofa, Wild boar

\section{Findings}

Porcine brucellosis can be caused by three biovars (1-3) of Brucella suis. Biovar 2 is an important pathogen in wild boars (Sus scrofa) with a broad geographical distribution ranging from Scandinavia to the Balkan region [1]. Systematic brucellosis monitoring in wildlife is not demanded by regulatory acts but several studies have reported the presence of this infection in European countries [2-9]. Scientific data on the prevalence of $B$. suis biovar 2 in the Baltic countries, Russia and Belorussia have not been published. A few cases of domestic pig brucellosis have been recorded in Estonia (2006) and Latvia (2007 and 2008) [10]. The latest outbreak in Latvia was in 2010 in the western part of the country (unpublished observations).

\footnotetext{
*Correspondence: lelde.grantina-ievina@bior.lv

Animal Disease Diagnostic Laboratory, Institute of Food Safety, Animal

Health and Environment "BIOR", 3 Lejupes Street, Riga 1076, Latvia
}

Transmission of Brucella bacteria occurs during copulation and by consumption of infected birth and abortion products and uterine discharges. Infection is not necessarily associated with the presence of gross lesions [11]. Wild boars as well as the European hare (Lepus capensis) are considered as reservoirs for transmissions of $B$. suis biovar 2 to domestic livestock [1], mainly due to consumption of offal from hunted or dead infected hares by wild boars [10].

According to estimates made by the Latvian State Forest Service, the population of wild boars in Latvia increased during the last decades from around 15,000 in 1997 to 74,000 in 2013, but decreased to 49,000 in 2015 due to promoted hunting. The estimated population of European hares in Latvia is 34,700, indicating the potential for transmission of the infection from this host [12].

The aim of the present study was to determine the seroprevalence of brucellosis in wild boars in the eastern part of Latvia and its correlation to gender and age. 
Blood and tissue samples (spleen, kidney, tonsil and lymph nodes) were collected from wild boars killed by hunters from January to April $2015(\mathrm{n}=877)$ and from March to April $2016(\mathrm{n}=167)$ conducted within the national surveillance programs aimed on African and classical swine fever viruses. Hunters determined gender of the animals and age based on tooth eruption pattern $(<12,12-24,>24$ months). All tested animals were evaluated as clinically healthy by hunters and veterinarians, i.e. no obvious clinical or pathological signs of brucellosis were observed.

Samples were transported to the laboratory refrigerated at $4{ }^{\circ} \mathrm{C}$. Blood samples were transferred to $5 \mathrm{ml}$ tubes, centrifuged and kept at $4{ }^{\circ} \mathrm{C}$ until analysis but not longer than 5 days. The tissue samples were kept at $-20^{\circ} \mathrm{C}$ until analysis.

Sera were tested by the Rose Bengal test (RBT) (Rose Bengal assay, IDEXX, Westbrook, USA) and a complement fixation test (CFT) according to the OIE Manual of Diagnostic Tests and Vaccines for Terrestrial Animals [1] and Standard Operating Procedures of European Union Reference Laboratory for Brucellosis [13, 14]. For the CFT, the following compounds were used: Brucella antigens (IDEXX or IDvet, Grabels, France), sheep blood in Alsvers (TCS Biosciences Ltd, Botolph Claydon, UK), rabbit haemolytic serum (TCS Biosciences Ltd), calcium-magnesium veronal buffer (IDvet) and guinea pig complement (IDvet). Samples were recorded as seropositive if either the RBT and/or CFT was positive, and these were further tested with indirect enzyme-linked immunosorbent assays (ELISAs) (Ingezim Brucella porcina, Ingenasa, Madrid, Spain) and screened for presence of Yersinia enterocolitica antibodies by an indirect ELISA (Pigtype Yopscreen, Labor Diagnostik Leipzig, Leipzig, Germany).

To identify individuals suitable for Brucella isolation, i.e. animals with an expected high bacterial load, total DNA was extracted from 78 pooled tissue specimens of seropositive animals (strong positive RBT $(\geq 1+)$ and/or CFT ( $\geq 23.33 \mathrm{IU} / \mathrm{ml}$ ); $\mathrm{n}=42$ in 2015 and $\mathrm{n}=36$ in 2016). Extracted DNA was subjected to IS711-based nested polymerase chain reaction (PCR) [15]. In the case of positive PCR, tissues from 20 animals in 2015 and nine animals in 2016 were subjected to bacteriological culturing. Culturing was done on spleen, kidney, tonsil and lymph nodes separately, according to $[1,16]$. Biovar determination was done by further cultivation on selective agar with/ without $\mathrm{CO}_{2}$, the $\mathrm{H}_{2} \mathrm{~S}$ test, growth in the presence of dyes (thionin and basic fuchsin), slide agglutination tests with monospecific A, M, R antisera and lysis by phages according to $[1,17]$. These tests were followed by species and biovar confirmation with species specific PCR [18] and Bruce-ladder multiplex PCR [19].
Statistical analyses were done using $\mathrm{R}$ program [20] and Chi square test [21]. True prevalence was calculated using EpiTools epidemiological calculators [22].

In 2015, the sampling area covered 40 municipalities with a total area of $30,177 \mathrm{~km}^{2}$. A total of 199 animals [22.7\%; 95\% confidence interval (CI) 20.04-25.58] were seropositive for Brucella. In 2016, the sampling area covered 18 regional municipalities with a total area of $18,461 \mathrm{~km}^{2}$. Of the 167 tested animals, 36 (21.6\%; CI 16.0-28.4) were serologically positive for Brucella. Data of both study years are combined in Table 1. In 2015, $130(65.3 \%)$ of the seropositive animals were also seropositive to $Y$. enterocolitica, while this was the case for 32 (88.9\%) animals in 2016 (Table 2). Due to cross-reactivity between $B$. suis and $Y$. enterocolitica in serological tests, serology data were combined with PCR results revealing a prevalence of B. suis biovar 2 infection of 14.0 and $9.6 \%$ in 2015 and 2016, respectively. This level of exposure to B. suis is relatively low compared to that in certain other European countries. Serological surveys have reported the proportion of seropositive animals estimated by microagglutination test and CFT to be as high as $15.0 \%$ in the Czech Republic (1995-1996) [3], while estimations using RBT and CFT were $19.7 \%$ in Italy (2001-2007) [6], and 22.6-29.4\% in Croatia (1996-2000), and estimations based on ELISA were $22.0 \%$ in north-eastern Germany (1995-1996) [5], up to $39.6 \%$ in some cantons of Switzerland (2001-2003) [8], and on average $24.4 \%$ in Poland (2012) [9]. Among these investigations the cross-reactivity problem of serological tests with $Y$. enterocolitica was assessed only in Germany [5].

The density of seropositive wild boars in 2015 ranged from 0 to 5 animals per $100 \mathrm{~km}^{2}$ (Fig. 1). The number of tested animals ranged from 0.2 to 12 animals per $100 \mathrm{~km}^{2}$. The regions with the highest numbers of serologically positive animals $\left(2-5\right.$ per $\left.100 \mathrm{~km}^{2}\right)$ where those with relatively high numbers of hunted and tested animals. The seroprevalence in these regions ranged from $25.0 \%$ (in Baltinavas and Rujienas regions) to $42.4 \%$ (Nauksenu region). The density of seropositive wild boars in 2016 ranged from 0 to 0.5 animals per $100 \mathrm{~km}^{2}$. The number of tested animals ranged from 0.1 to 3.8 animals per $100 \mathrm{~km}^{2}$ (data not shown).

In 2015, 24 pooled tissue samples from 42 seropositive animals were positive by the IS711-based nested PCR assay (Table 2) and B. suis biovar 2 was isolated from 12 of 20 samples, of which 15 originated from PCR positive animals. In most of the cases, isolation from the spleen samples was successful. In 2016, 18 of 36 tissue samples from seropositive animals were positive for IS711 by PCR. B. suis biovar 2 was cultured from 9 of 9 selected PCR positive samples. 


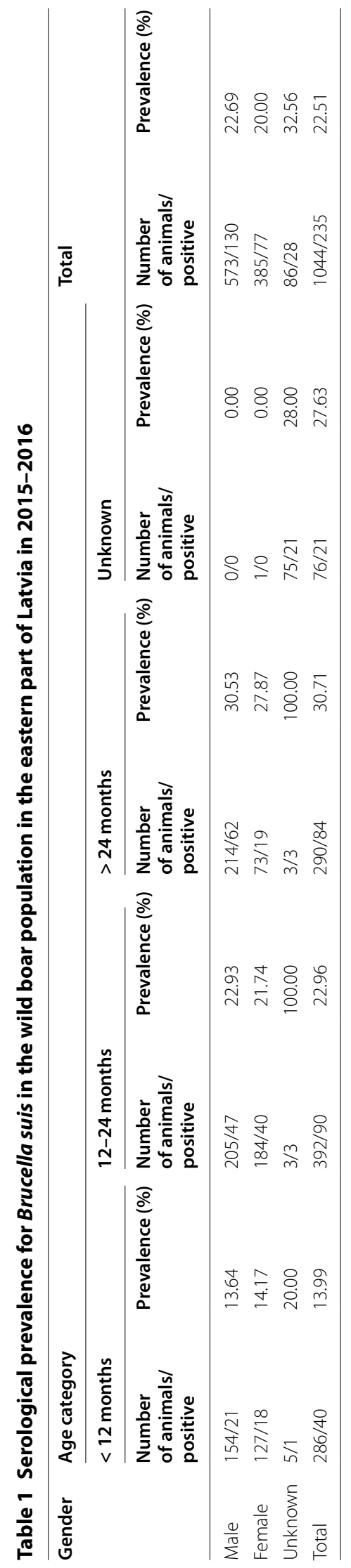


Table 2 Comparison of nested polymerase chain reaction results with the Rose Bengal test, complement fixation test, and indirect enzyme-linked immunosorbent assays of swine brucellosis and Y. enterocolitica in $2015(n=42)$ and 2016 $(\mathbf{n}=36)$

\begin{tabular}{|c|c|c|c|c|c|c|c|c|}
\hline \multirow[t]{2}{*}{ PCR result } & \multicolumn{2}{|c|}{ RBT 2015/2016 } & \multicolumn{2}{|c|}{ CFT 2015/2016 } & \multicolumn{2}{|c|}{ ELISA 2015/2016 } & \multicolumn{2}{|c|}{$\begin{array}{l}\text { ELISA Y. enterocol- } \\
\text { itica } 2015 / 2016\end{array}$} \\
\hline & Pos & Neg & Pos & Neg & Pos & $\mathrm{Neg}$ & Pos & Neg \\
\hline Positive & $24 / 18$ & NT & $19 / 16$ & $5 / 2$ & $23 / 18$ & $1 / 0$ & $10 / 16$ & $14 / 2$ \\
\hline Negative & $18 / 18$ & NT & $18 / 9$ & NT/7 & $18 / 14$ & $\mathrm{NT} / 4$ & $16 / 15$ & $2 / 2$ \\
\hline
\end{tabular}

RBT, Rose Bengal test; CFT, complement fixation test; ELISA, Ingezim Brucella porcina; ELISA Y. enterocolitica, Pigtype Yopscreen; Pos, positive; Neg, negative; NT, not tested

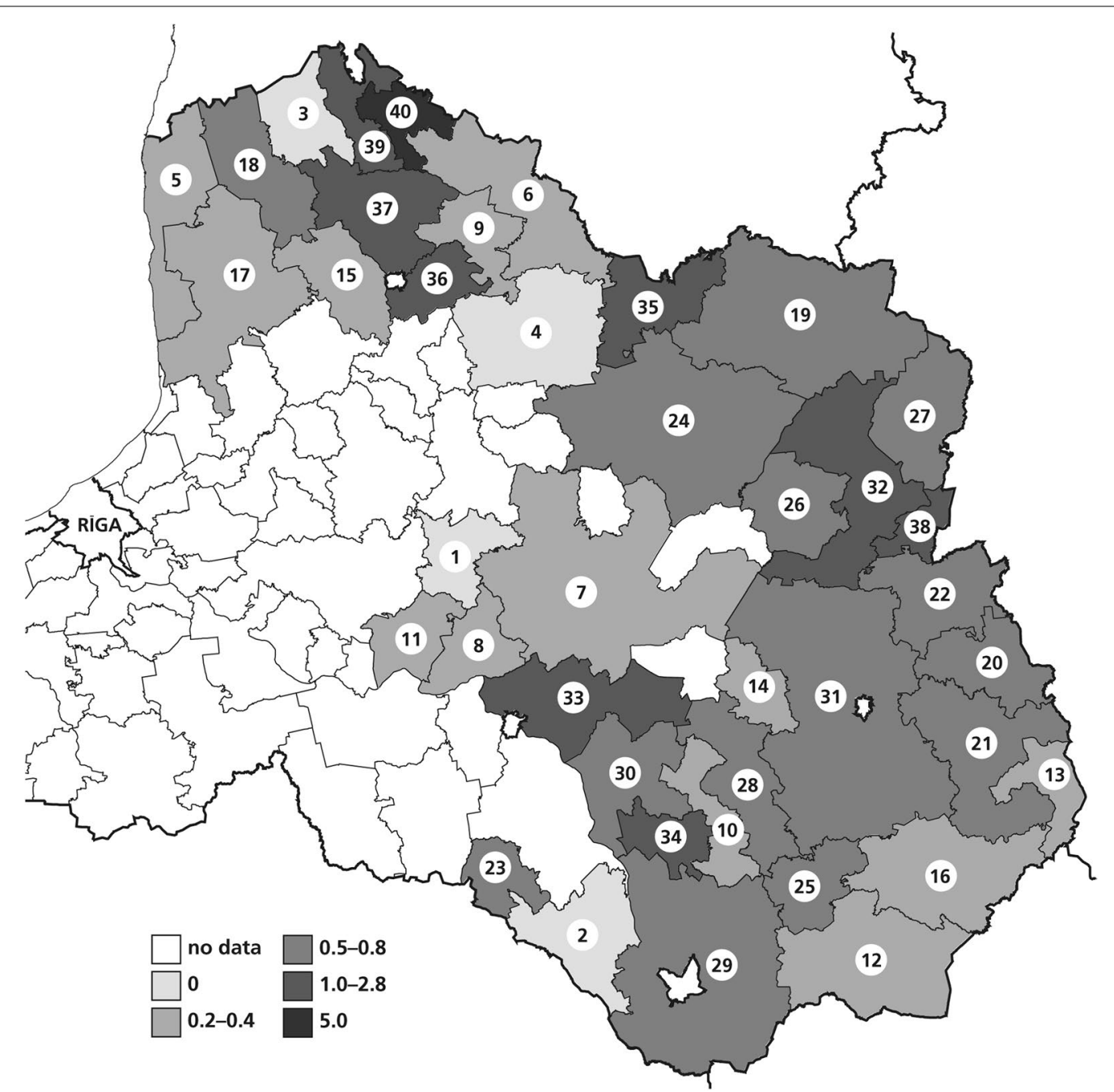

Fig. 1 Average density of infected wild boars estimated as serologically positive animals per $100 \mathrm{~km}^{2}$ (2015). Regions: 1-Erglu, 2-Ilukstes, 3Mazsalacas, 4-Smiltenes, 5-Salacgrivas, 6-Valkas, 7-Madonas, 8-Plavinu, 9-Strencu, 10-Preilu, 11—Kokneses, 12-Kraslavas, 13-Zilupes, 14-Vilanu, 15-Kocenu, 16-Dagdas, 17-Limbazu, 18-Alojas, 19-Aluksnes, 20-Ciblas, 21—Ludzas, 22-Karsavas, 23-Aknistes, 24-Gulbenes, 25-Aglonas, 26-Rugaju, 27-Vilakas, 28-Riebinu, 29-Daugavpils, 30—Livanu, 31-Rezeknes, 32-Balvu, 33-Krustpils, 34-Varkavas, 35-Apes, 36-Beverinas, 37-Burtnieku, 38-Baltinavas, 39-Rujienas, 40-Nauksenu 
The prevalence of seropositive boars did not differ between genders. The prevalence of seropositive boars was positively correlated with increased age irrespectively of gender for 2015 samples $\left(X^{2}=14.6, P=0.0007\right.$ for males and $\chi^{2}=6.26, P=0.04$ for females). Positively correlated seroprevalence among age groups have been observed also in other countries, for example, in Italy [6], and a sex/age interaction was found in Spain [23]. In 2016 differences between age categories were statistically not significant probably due to the low number of tested animals in this year.

Statistically significant differences were obtained also by sampling month in $2015\left(x^{2}=17.6, \mathrm{P}=0.0005\right)$ with the highest prevalence in April (36.8\%). Significant differences among sampling seasons have been recorded also in other investigations, for example, in Spain in relation to hunting activities [23].

The seroprevalence in some regions of eastern Latvia was $25.0-42.4 \%$. These areas corresponded to regions with the highest percentage of forest area $(57 \%)$ compared to the average forest area of $50 \%$ in Latvia in general [12]. A high degree of forest area is probably positively correlated with a high density of wild boars. It has been estimated that $89 \%$ of the territory of Latvia contains habitat suitable for wild boars [24]. The average seroprevalence for $B$. suis in Latvian wild boars seems to be relatively low in comparison to certain other European countries but still the wild boar population has to be considered as an important reservoir for the B. suis biovar 2 transmission to domestic pigs.

\section{Abbreviations \\ Cl: confidence interval; CFT: complement fixation test; ELISA: enzyme-linked immunosorbent assay; LPS: lipopolysaccharide; NT: not tested; PCR: polymer-} ase chain reaction; RBT: Rose Bengal test.

\section{Authors' contributions}

IR and DK planned the study. ZS and IV carried out the serological tests. JA and MS did the microbiological analyses. SC performed the molecular tests. LG-I prepared the manuscript. All authors read and approved the final manuscript.

\section{Acknowledgements}

Not applicable.

\section{Competing interests}

The authors declare that they have no competing interests.

\section{Availability of data and materials}

The datasets used and/or analyzed during the current study are available from the corresponding author on reasonable request.

\section{Consent for publications}

Not applicable.

Ethics approval and consent to participate Not applicable.

\section{Funding}

The study was financed by the Ministry of Agriculture of Latvia within the state budget program [Grant Number 20.02.00]. The sponsors were not involved in study design, in the collection, analysis and interpretation of data, in the writing of the report, and in the decision to submit the article for publication.

\section{Publisher's Note}

Springer Nature remains neutral with regard to jurisdictional claims in published maps and institutional affiliations.

Received: 19 September 2017 Accepted: 15 March 2018

Published online: 24 March 2018

\section{References}

1. The World Organisation for Animal Health: manual of diagnostic tests and vaccines for terrestrial animals. Chapter 2.1.4. Brucellosis (Brucella abortus, B. melitensis and B. suis) (infection with B. abortus, B. melitensis and B. suis). 2016. http://www.oie.int/en/international-standard-setting/terrestrialmanual/access-online/. Accessed 14 Aug 2016.

2. Garin-Bastuji B, Hars J, Calvez D, Thiebaud M, Artois M. Brucellose du porc domestique et du sanglier sauvage due à Brucella suis biovar 2 en France. Rev Epid San Anim. 2000:38:1-5.

3. Hubálek Z, Treml F, Juřicová Z, Huňady M, Halouzka J, Janík V, et al. Serological survey of the wild boar (Sus scrofa) for tularaemia and brucellosis in South Moravia, Czech Republic. Vet Med Czech. 2002;47:60-6.

4. Cvetnic Z, Mitak M, Ocepek M, Lojkic M, Terzic S, Jemersic L, et al. Wild boars (Sus scrofa) as reservoirs of Brucella suis biovar 2 in Croatia. Acta Vet Hung. 2003;51:465-73.

5. Al Dahouk S, Nockler K, Tomaso H, Splettstoesser WD, Jungersen G, Riber $\mathrm{U}$, et al. Seroprevalence of brucellosis, tularemia, and yersiniosis in wild boars (Sus scrofa) from north-eastern Germany. J Vet Med B Infect Dis Vet Public Health. 2005;52:444-55.

6. Bergagna S, Zoppi S, Ferroglio E, Gobetto M, Dondo A, Di Giannatale E, et al. Epidemiologic survey for Brucella suis biovar 2 in a wild boar (Sus scrofa) population in Northwest Italy. J Wild life Dis. 2009:45:1178-81.

7. Leuenberger R, Boujon P, Thur B, Miserez R, Garin-Bastuji B, Rufenacht J, et al. Prevalence of classical swine fever, Aujeszky's disease and brucellosis in a population of wild boar in Switzerland. Vet Rec. 2007;160:362-8.

8. Abril C, Thomann A, Brodard I, Wu N, Ryser-Degiorgis M-P, Frey J, et al. A novel isolation method of Brucella species and molecular tracking of Brucella suis biovar 2 in domestic and wild animals. Vet Microbiol. 2011:150:405-10.

9. Szulowski K, Iwaniak W, Złotnicka J, Szymajda M, Weiner M, Lipowski A, et al. Survey of the anti-Brucella antibody status determined by ELISA testing in wild boars in Poland. Med Weter. 2015;71:215-8.

10. European Food Safety Authority. Scientific opinion of the panel on Animal Health and Welfare (AHAW) on a request from the commission on porcine brucellosis (Brucella suis). EFSA J. 2009;1144:1-112.

11. Godfroid J. Brucellosis in wildlife. Rev Sci Tech Off Int Epiz. 2002;21:277-86.

12. State Forest Service: numbers and facts. 2016. http://www.vmd.gov.lv/ valsts-meza-dienests/statiskas-lapas/medibas/valsts-meza-dienests/ statiskas-lapas/skaitli-un-fakti?id=766\#jump. Accessed 14 Aug 2016.

13. European Union Reference Laboratory for brucellosis: standard operating procedure. Rose Bengal test. 2010. https://sites.anses.fr/en/minisite//ruebrucellose/standard-operating-procedures. Accessed 18 Jan 2016.

14. European Union Reference Laboratory for brucellosis: standard operating procedure. Complement fixation test. 2010. https://sites.anses.fr/en/ minisite//rue-brucellose/standard-operating-procedures. Accessed 18 Jan 2016.

15. Bounaadja L, Albert D, ChenaisB Henault S, Zygmunt MS, Poliak S, et al. Real-time PCR for identification of Brucella spp.: a comparative study of IS711, bcsp31 and per target genes. Vet Microbiol. 2009;137:156-64.

16. European Union Reference Laboratory for brucellosis: standard operating procedure. Brucella culture and genus identification. 2011. https://sites. anses.fr/en/minisite/lrue-brucellose/standard-operating-procedures. Accessed 18 Jan 2016. 
17. Alton GG, Jones LM, Angus RD, Verger JM. Techniques for the brucellosis laboratory. Paris: Institut National de la Recherche Agronomique; 1988.

18. Viljoen GJ, Nel LH, Crowther JR. Molecular diagnostic PCR handbook. Berlin: Springer; 2005.

19. Lopez-Goni I, García-Yoldi D, Marín CM, de Miguel MJ, Munoz PM, Blasco $J M$, et al. Evaluation of a multiplex PCR assay (Bruce-ladder) for molecular typing of all Brucella species, including the vaccine strains. J Clin Microbiol. 2008;46:3484-7.

20. R Development Core Team. R: A language and environment for statistical computing. R Foundation for Statistical Computing, Vienna, Austria. 2017. ISBN 3-900051-07-0, URL http://www.R-project.org/. Accessed 18 Jan 2017.

21. Social Science Statistics. 2016. http://www.socscistatistics.com/. Accessed 14 Aug 2016.
22. EpiTools epidemiological calculators. Ausvet Pty Ltd. 2018. http://epitools. ausvet.com.au/. Accessed 26 Jan 2018.

23. Munoz PM, Boadella M, Arnal M, de Miguel MJ, Revilla M, Martinez D, et al. Spatial distribution and risk factors of brucellosis in Iberian wild ungulates. BMC Infect Dis. 2010;10:46.

24. De la Torre A, Bosch J, Iglesias I, Munoz MJ, Mur L, Martınez-Lopez B, et al. Assessing the risk of African swine fever introduction into the European Union by wild boar. Transbound Emerg Dis. 2015;62:272-9.

\section{Submit your next manuscript to BioMed Central and we will help you at every step:}

- We accept pre-submission inquiries

- Our selector tool helps you to find the most relevant journal

- We provide round the clock customer support

- Convenient online submission

- Thorough peer review

- Inclusion in PubMed and all major indexing services

- Maximum visibility for your research

Submit your manuscript at www.biomedcentral com/submit 